\title{
The Effect of Due Professional Care, Integrity, Confidentiality, and Independence on Audit Quality
}

\author{
(An Insight of East-Java Auditors in Indonesian During Pandemic)
}

\author{
Dwirezki Octaviani*, Jaswadi, Kurnia Ekasari \\ Accounting Department \\ State Polytechnic of Malang \\ Malang, Indonesia \\ *dwirezkie04@gmail.com,jaswadi@polinema.ac.id, kurnia.es@yahoo.com.au
}

\begin{abstract}
This study aimed to analyze the effect of due professional care, integrity, confidentiality, and independence on audit quality. Moreover, define the most required topic of advanced professional training related to increase the professionalism of auditor which was appropriate in this pandemic. The object of the research were public accountant firms in East Java, Indonesia. The data were collected through questionnaires which was conducted during the pandemic. Based on the sample collection using purposive sampling method, the number of samples from this study were 14 public accountant firms. The analytical method used was multiple linear regression which was processed using SPSS 25 . The results showed that the due professional care and integrity variables had effect on audit quality. On the other hands confidentiality and independence had no effect on audit quality. In addition, all of variables had significant effect on audit quality simultaneously. Moreover, the result based on top of mind questionnaires model showed that the most required advanced professional training topic was quality assurance system topic which was appropriate in this pandemic. The result of this study was expected to help the manager or stakeholder who require the information on financial statement to make sure the quality of audit result thus could make a reliable decision and could be the consideration of internal management on Public Accountant Firms to adjust the quality assurance system of audit process during this pandemic.
\end{abstract}

Keywords-due professional care, integrity, confidentiality, independence, audit quality, advanced professional training

\section{INTRODUCTION}

The Company needs third party services to confirm its financial statement which accounted by stakeholders to make the important decision. The third party service or the auditor is required by management and controlling shareholder to make sure the financial statement is reliable. Based on the phenomena, there were some corporate scandals caused by auditors which already made the Public Accountant Profession become the spotlight and decrease the user's trust among the auditors. As an auditors processing audit result must to consent of the standard and regulation of auditors called code of professional ethic. At the fact there are the dilema situation between the implementation of the principle of professional ethic and the client's interest. On the first side the auditors must to be independent in giving opinions on the fairness of financial statement. But on another side the auditors are required to meet the demand desired by client who pay fees for audit. This kind of concept or principle which become the foundation for auditors who should finish base on independence, competency, and accountability use their capability carefully and thoroughly and also uphold code of conduct to achieve audit quality. It is important to improve the audit quality, by analyzing the factors that affect audit quality. Auditors should keep and improve the code of conduct in conducting their engagement, therefore the audit quality increases. In the Introduction section, present clearly and briefly the problem investigated, with relevant references. Various inconsistencies of research results related to audit quality open up the opportunities for researchers to reexamine the factors affect audit quality including due professional care, integrity, confidentiality, and independence.

This research used attribution theory, attribution theory is a theory that explains the effect and motive of someone's behavior. This theory shows how a person explains the reason for someone's behavior which caused by external and internal factors of a person. This research used attribution theory because it was conducted an empirical study which examined the factors affect audit quality especially due professional care, integrity, confidentiality and independence that are the internal factor from auditor's self. The internal factor is one of the keys that affect audit quality and support auditors among conducting their job and assignment audit. This research analyzes the topic related to auditor's self-theory that can be measured eith the code of professional ethics in audit standard. Knowing how the auditors decide will give the information about the performance during the audit process.

The Audited Financial provided are reliable and according to the standard in Indonesia (SAK/ETAP/IFRS). Based on Laws of Private Company number 40 in 2007 article 68 states that a company that has the amount of gross income above 50 
Billion should be audited. More over base on rules on trade ministry number 25 in 2020 release on March states that Company and State-Owned Company should be audited for the companies which have asset more than IDR. 25 Billion might include its audited financial statement to Bapepam maximum about 9 months after closing the book of accounting's Year. audit quality is a possibility that gotten in conducting an audit activity where an auditor will find and report a fraud on client's accounting system [1]. The possibility that the auditor will find misstatement depends on the competence of the auditor while reporting misstatement depends on the auditor's independence. The High audit quality can affect the reliability of financial statements in helping the decision making by users of financial statements [2]. An auditor has to allow all of principle of professional ethic that consists of integrity, objectivity, due professional care, confidentiality. Because at the professional practice there are many issues related in professional ethic. When the auditor starts to solve the crush between the application and the principle of code of professional ethic will be relevance for using of crush issues solving, consist of the facts that relevance, etic issues that occur often, professional etic principle that become a reason of an issues, the internal procedure, and some alternative action.

Due professional care is meant careful and professional skills carefully thought out. Due professional care is one factor that must be owned by an auditor's personality in carrying out professional work that can influence high audit quality [3]. The importance of training for an auditor is expressed in the Regulations Republic of Indonesia Supreme Audit Board number 01 of 2007 concerning Financial Inspection Standards state, each examiner who carry out checks according to inspection standards, every 2 (two) years must complete at least 80 (eighty) hours of education in a manner directly enhance the examiner's professional skills to implement examination. At least 24 (twenty-four) hours from 80 hours of education it must be in matters directly related to the above examination management and responsibility of state finances within the government or the special and unique environment in which the entity examined operates. There were inconsistency research results on this topic. Due professional care had positive significant effect on audit quality [4] which supported by another the research [5]. Due professional care had no significant effect on audit quality [6]

Integrity as a concept of consistency actions, values, methods, steps, principles, expectations, results and integrity is considered as honesty and truth which is the accuracy of someone's actions. It is also regulated in the Accounting Professional Code of Ethics where the principle of integrity requires every practitioner to be firm, honest, fair in his professional and business relations. This principle also stipulates that practitioners should not have any connection with reports, communications or other information that believed to have material errors, the information provided inadvertently and omissions that may mislead information that should be disclosed. (Code of Professional Ethics in Public Accountants, IAPI,). Integrity had a significant effect on audit quality [7], this research was in line with the research conducted by Baisary [8]. In another hand these results were reverse with the research conducted by Purnomo stated that integrity had no significant effect on audit quality [9].

Confidentiality is required to make an auditor has the responsibility to keep the information from the client and does not disclose it without any approval [10]. PER / 04 / M.PAN / $03 / 2008$ states that an auditor is required to respect the value and ownership of the information it receives and does not disclose such information without adequate writerization, except required by applicable regulations. Auditors are required to preserve all confidentiality of information obtained by the inspection object. By guarding confidentiality, auditors can work professionally therefore they will affect the quality of inspection reports that are one assessment of auditor performance [11]. Confidentiality affected on audit quality [8].

In providing professional services, the Public Accounting Firm must preserve a mental attitude following the professional standards of the public accountant determined by IAI [12]. Independence is one of the most important characteristics of an auditor. The reason for many financial statement users depend on external audit reports is because they expect an unbiased view from the auditor [13]. An independent auditor is an auditor that is not easily influenced because they do their job based on responsibility of trust to the company and stakeholder. states that independence variables do not significantly affect audit quality [4]. Independensi has more dominan impact toward audit quality [5]. In reality, auditors often have difficulty maintaining an independent mental attitude. Independence had a significant effect on audit quality [6]. This result was in line with the research conducted by Elisha, et al [5]. Independence had no significant effect on audit quality [2].

\section{METHODS}

\section{A. Data Collection Method}

This research used the primary data, the data was gotten through respondents directly. Primary data was chosen because it can show the newest and reliable information. Besides that it used the secondary data, the data was gotten through the understanding and analyze of many literatures which related to this research. This research used a survey method, by questionnaires that were distributed to respondents. Collect with purposive sampling method. The questionnaire is a closed type which has some choice to answer the question for respondents. This research does use the Literature of the same research which has been conducted. So could be gotten the related theory to support this research as the reference material and consideration.

\section{B. Objectives of the Study}

The respondents in this research are auditors from Public Accounting Firms (PAFs) in East Java, Indonesia. The reason for choosing the Public Accountant Firm in East Java is because as a huge province there are many Public Accounting Firms and most of them are a big Public Accountant Firm. This 
study using a non-probability method that is purposive sampling. Purposive sampling is sampling based on certain criteria over a group of targets. These criteria are all Auditors who work at Public Accounting Firm in East Java that have followed audit procedures. The auditors used as respondents in this study are auditors at the Public Accounting Firm who have conducted audit procedures on the financial statements to provide an opinion on the results of the audit and can be said to be directly involved in determining the level of audit results. Another reason for choosing auditors who work at the Public Accounting Firm East Java is to manage the costs and time during the study was conducted.

Totally there were 50 questionnaires sent to respondents at each Public Accountant Firm, the total number of questionnaires returned were 2 questionnaires (96\% response rate). Of the returned questionnaires, as many as a questionnaire were eligible and used in the analysis (response rate $96 \%$ ) while the remaining questionnaires were not responded to and some questionnaires were not eligible. The questionnaire that was not responded was caused by there was a Public Accountant Firm who confirmed the approval about the fill in the questionnaires but after the questionnaires link was shared there was no auditors from that Public Accountant Firm fill in the questionnaires.

\section{Data Analysis}

This research used descriptive statistic, descriptive statistics were used to determine and be able to explain the characteristics of the research variable in a situation) [14]. And used multiple regression connecting one dependent variable with several independent variables in a model of mathematical equations for hypothesized relationships can be formulated as follows: $\mathrm{Y}=\alpha+\beta 1 \mathrm{X} 1+\beta 2 \mathrm{X} 2+\beta 2 \mathrm{X} 3+\beta 2 \mathrm{X} 4+\mathrm{e}$, where: $\alpha=$ constant, $\mathrm{Y}=$ Audit Quality as dependent variable, $\mathrm{X} 1=$ the independent variable called due professional care, $\mathrm{X} 2=$ integrity, X3 = Confidentiality, X4 = independence and e = error term. T test is used to test the hypothesis partially to show the effect of each independent variable individually to the dependent variable. The $t$ test is the test of the regression coefficient of each independent variable to the dependent variable to find out how much influence the independent variable to the dependent variable.

\section{RESULTS AND DISCUSSION}

Totally there were 50 questionnaires sent to respondents at each Public Accountant Firm, the total number of questionnaires returned were 2 questionnaires (96\% response rate). Of the returned questionnaires, as many as a questionnaire were eligible and used in the analysis (response rate $96 \%$ ) while the remaining questionnaires were not responded to and some questionnaires were not eligible. The questionnaire that was not responded was caused by there was a Public Accountant Firm who confirmed the approval about the fill in the questionnaires but after the questionnaires link was shared there was no auditors from that Public Accountant Firm fill in the questionnaires.

This research data has already passed the validity testing, multicollinearity, and heteroscedasticity testing. Then could be conducted the hypothesis testing to define the effect of all factors on audit quality, namely due professional care, integrity, confidentiality and independence. The result of multiple linier regression analysis could be seen as the table 1 below:

TABLE I. MULTIPLE LINIER REgRESSION ANALYSIS RESUlTS

\begin{tabular}{|c|c|c|c|c|c|c|}
\hline & \multirow{2}{*}{ Model } & \multicolumn{2}{|c|}{$\begin{array}{c}\text { Unstandardized } \\
\text { Coefficients }\end{array}$} & \multirow{2}{*}{$\begin{array}{c}\begin{array}{c}\text { Standardized } \\
\text { Coefficients }\end{array} \\
\text { Beta }\end{array}$} & \multirow{2}{*}{$\mathbf{t}$} & \multirow{2}{*}{ Sig. } \\
\hline & & B & $\begin{array}{c}\text { Std. } \\
\text { Error }\end{array}$ & & & \\
\hline \multirow{5}{*}{1} & (Constant) & 2,263 & 4,018 & & 0,563 & 0,576 \\
\hline & $\begin{array}{l}\text { Due Professional } \\
\text { Care }\end{array}$ & 0,464 & 0,265 & 0,241 & 2,246 & 0,000 \\
\hline & Integrity & 0,895 & 0,165 & 0,709 & 5,420 & 0,000 \\
\hline & Confidentiality & $-0,209$ & 0,256 & $-0,116$ & $-0,816$ & 0,419 \\
\hline & Independence & 0,225 & 0,177 & 0,121 & 1,273 & 0,210 \\
\hline
\end{tabular}

$\mathrm{Y}=\mathrm{a}+\mathrm{b}_{1} \mathrm{X}_{1}+\mathrm{b}_{2} \mathrm{X}_{2}+\mathrm{b}_{3} \mathrm{X}_{3}+\mathrm{b}_{4} \mathrm{X}_{4}+\mathrm{e}$

$\mathrm{Y}=2,263+0,464 \mathrm{X}_{1}+0,895 \mathrm{X}_{2}+\left(-0,209 \mathrm{X}_{3}\right)+0,225 \mathrm{X}_{4}+\mathrm{e}$

The model can be interpreted as follows:

- Regression coefficient variable X1 (due professional care) obtained by 0.464 with positive coefficient direction. This shows that higher due professional care can improve audit quality in financial examination.

- Regression coefficient of variable X2 (Iintegrity) obtained by 0,895 with positive coefficient direction. This shows that higher iintegrity can improve audit quality in financial
- The regression coefficient of variable X3 (confidentiality) is obtained at 0.209 with positive coefficient direction. This shows that higher confidentiality can not improve significantly audit quality in financial audit.

- The significance value obtained for the independence variable was $0.210>0.05$ with a regression coefficient at 0,225 . This means that the fourth hypothesis are rejected, or independence has no partially effect on the audit quality. 
TABLE II. RESULT OF TEST RESUlT

\begin{tabular}{|l|l|l|l|l|c|}
\hline \multicolumn{1}{|c|}{ Model 1 } & $\begin{array}{c}\text { Sum of } \\
\text { Squares }\end{array}$ & df & $\begin{array}{c}\text { Mean } \\
\text { Square }\end{array}$ & F & Sig. \\
\hline Regression & 477,184 & 4 & 119,296 & 30,971 & 0,000 \\
\hline Residual & 165,629 & 43 & 3,852 & & \\
\hline Total & 642,813 & 47 & & & \\
\hline
\end{tabular}

$T$ count and $F$ count :

$\mathrm{f}$ table $=\mathrm{f}(\mathrm{k} ; \mathrm{n}-\mathrm{k})=\mathrm{f}(4 ; 44)$

f table : 2,58

$\mathrm{f}$ count $=30,971$ is greater than $\mathrm{f}$ table 2,58

sig : 0,05 is greater than 0,00

\section{A. Interpretation}

1) F statistical testing: It states that $\mathrm{F}$ has the value of 30,971 with a significance value of $\mathrm{P}$ value 0,000 which smaller than $\alpha=0.05$. So it can be concluded that the regression model which used was considered feasible test and all of independent variables are able to explain the phenomenon of audit quality.

2) $T$ statistical testing: The statistical testing t basically shows the effect of each independent variables explain the dependent variable. The testing criteria is based on the probability of more significance which smaller than $0.05(\alpha)$, then the independent variables individually affect dependent variable (Ghozali, 2011). The level of significance of the due professional care variable equals 0.000 is less than the level significance at 0.05 , then hypothesis 1 is accepted. This proves that due professional care influences the audit quality and the direction of their influence positive $(\beta=0,464)$ with a $t$ statistic value of 2,246. This means the improving of due professional care conducted by the auditor, is strengthening the audit quality.

Statistical tests show that the level of significance of integrity variable equals 0,000 is less than the significance level at 0.05 then hypothesis 2 is accepted. This proves that the integrity variable affects the audit quality and the direction of its influence is positive $(\beta=0,895)$ with a t-statistic value of 5,420 . This means the increasing of integrity of auditor, enhance the audit quality. Moreover, the level of significance of confidentiality variables equals 0,412 is more than the significance level at 0,05 then hypothesis 3 is rejected. This proves that the integrity variable does not affect significantly on audit quality and the direction of its influence is negative $(\beta$ $=-0,209)$ with a t-statistic value of $-0,816$.This means that the improving of the confidentiality will make audit quality decline. The level of significance of the independence variable equals 0,210 is more than significance level at 0,05 then hypothesis 4 is not accepted which proves that independence has no influence on audit quality. In addition, the direction is positive $(\beta=0,225)$ with $\mathrm{t}$-statistics 1,273 . Means the higher auditor's independence, decline audit quality.

Based on the developing questionnaires "Top of Mind" model, was found the most interesting and important topic of advanced professional training on auditors 'opinion. The Data examined with SPSS as the table 3 bellows:

TABLE III. RESUlts of AdVANCE PROFESSIONAL TRAINING

\begin{tabular}{|l|l|l|l|l|l|l|l|}
\hline & Advance Professional Training Topic & N & Range & Min & Max & Sum & Mean \\
\hline M.2 & Quality assurance system & 48 & 5 & 2 & 7 & 291 & 6,06 \\
\hline M.1 & Professional code of ethic from the Professional & 48 & 6 & 1 & 7 & 254 & 5,29 \\
\hline M.3 & $\begin{array}{l}\text { Coaching } \\
\text { Accounting Center or PPPK }\end{array}$ & 48 & 6 & 1 & 7 & 207 & 4,31 \\
\hline M.4 & Capital market & 48 & 6 & 1 & 7 & 199 & 4,15 \\
\hline M.5 & Conventional and Islamic Banking & 48 & 6 & 1 & 7 & 172 & 3,58 \\
\hline M.6 & Non-bank financial industry & 48 & 6 & 1 & 7 & 155 & 3,23 \\
\hline M.7 & Audit of campaign funds & & & & 7 & 280 & 5,83 \\
\hline
\end{tabular}

Then can be concluded that based on the auditor's opinion the most important and the required topic during the Covid 19 pandemic is Quality assurance system of Public Accountant Firms which supported by the research from Fauji, et al stated that Quality assurance system affect audit quality of the auditors [15].

During the Covid 19 pandemic auditors should continue to comply with required standards which may necessitate different and enhanced consideration by auditors in the new circumstances. The alternative procedure is needed to gather sufficient appropriate audit evidence to support audit opinion or to modify the audit opinion.

\section{CONCLUSION AND SUGGESTION}

Based on the analysis result, it was concluded that due professional care and integrity have a positive effect of the audit quality but it was also concluded that confidentiality and independence do not have effect of the audit quality. Moreover, the improving of due professional care or integrity strengthening audit quality results, for independence and integrity have no significant effect on audit quality if they are implemented partially. While simultaneously, the four variables audit quality contribute to determine the dependent variable is more than half percent. This means that all variables in this research have a strong affected to audit quality simultaneously but some of them are affected from another independent variable which did not conducted in this research that can also determine audit quality. 
Related to the Covid 19 Challenge for many sectors including auditors, there should be an alternative procedure to face the current circumstance on audit process. This research inferred that the advance training topic which significant needed by the auditors is quality assurance system. The quality assurance system will increase the quality of the auditors in Public Accountant Firm to conduct every processes in auditing.

Based on the results of this research then could give the suggestion as [1]. The scope of this study was only carried out at the Public Accountant Firms in East Java therefore to get a general conclusion is necessary carried out more extensive research [2]. This research is only using the online questionnaires as a media to collect data from auditors, would be better if the next research is also using the direct approach beside the online questionnaires, although the daring approach is more efficient, however the direct approach is required to make sure another factors which cannot reach by daring method [3]. There are still another independent variable that affect audit quality that have not been explored in this research.

\section{REFERENCES}

[1] E. Suyono, "The effects of independence, experience, and accountability to the audit quality," in Asia-Pacific Business Research Conference, February, 2012, pp. 13-14.

[2] L.T. Tjun, E.I. Marpaung, and E. Setiawan, "Pengaruh kompetensi dan independensi auditor terhadap kualitas audit," 2012.

[3] E. Dwimilten and A. Riduwan, "FAKTOR-FAKTOR YANG MEMPENGARUHI KUALITAS AUDIT,” J. Ilmu dan Ris. Akunt., vol. 4, no. 4, 2015 .

[4] A.Y. Kertarajasa, T. Marwa, and T. Wahyudi, "The effect of competence, experience, independence, due professional care, and auditor integrity on audit quality with auditor ethics as moderating variable," 2019.
[5] E.M. Singgih and I.R. Bawono, "Pengaruh Independensi, Pengalaman, Due Professional Care dan Akuntabilitas Terhadap Kualitas Audit," Simp. Nas. Akunt. XIII, pp. 1-21, 2010.

[6] D. Chintria Sari, "Faktor-faktor yang berpengaruh terhadap kualitas audit auditor independen pada kantor akuntan publik (KAP) di Jawa Tengah." UNIVERSITAS STIKUBANK, 2015.

[7] P.A. Susilo and T. Widyastuti, "Integritas, Objektivitas, Profesionalime Auditor dan Kualitas Audit di Kantor Akuntan Publik Jakarta Selatan," J. Ris. Akunt. Perpajak., vol. 2, no. 01, pp. 65-77, 2015.

[8] R.P. Baisary, "Pengaruh Integritas, Obyektivitas, Kerahasiaan, Kompetensi, dan Komitmen terhadap Kinerja Auditor pada Kantor Perwakilan Badan Pengawasan Keuangan dan Pembangunan (BPKP) Provinsi Sulawesi Tengah,” . e-Jurnal Katalogis, vol. 1, no. 1, pp. 123134, 2013.

[9] S.D. Purnomo and D. Wahyono, "Pengaruh Integritas, Kompetensi, Objektivitas, Profesionalisme, Dan Due Professional Care Terhadap Kualitas Audit (Studi Empiris Persepsi Auditor pada KAP di Surakarta dan Yogyakarta).” Universitas Muhammadiyah Surakarta, 2017.

[10] U.I. Utami, K. Kamaliah, and R. Rofika, "Pengaruh Integritas, Obyektivitas, Kerahasiaan, Kompetensi, Dan Pengalaman Kerja Terhadap Kinerja Auditor Pada Inspektorat Provinsi Riau." Riau University, 2015.

[11] C. Erina and Z.B. Darwanis, "Pengaruh integritas, obyektivitas, kerahasiaan dan kompetensi terhadap kinerja aparat pengawasan internal pemerintah (Studi pada Inspektorat Aceh)," J. Akunt. Pascasarj. Univ. Syiah Kuala, vol. 2, no. 1, pp. 15-27, 2012.

[12] S. Agoes, “Auditing: Petunjuk praktis pemeriksaan akuntan oleh kantor akuntan publik," Jakarta: Salemba Empat, 2016.

[13] A.A. Arens, R.J. Elder, and M.S. Beasley, "Auditing dan jasa Assurance," Jakarta: Erlangga, 2008.

[14] Indonesian Accounting Association (IAA), Professional Standar of Public Accountant. Jakarta: Indonesia: Salemba Empat Publishing, 2010.

[15] L. Fauji, M. Sudarma, and M. Achsin, "Penerapan Sistem Pengendalian Mutu dalam Meningkatkan Kualitas Audit,” J. Akunt. Multiparadigma, vol. 6 , no. 1 , pp. 38-52, 2015. 